\title{
Circular Business Strategies and Quality of Life
}

\author{
Iben Bolund Nielsen * and Henri Hakala
}

Citation: Nielsen, I.B.; Hakala, H. Circular Business Strategies and Quality of Life. Sustainability 2022, 14, 1782. https://doi.org/10.3390/ su14031782

Academic Editors: Lasse Torkkeli and Susanne Durst

Received: 20 December 2021

Accepted: 2 February 2022

Published: 4 February 2022

Publisher's Note: MDPI stays neutral with regard to jurisdictional claims in published maps and institutional affiliations.

Copyright: (c) 2022 by the authors. Licensee MDPI, Basel, Switzerland. This article is an open access article distributed under the terms and conditions of the Creative Commons Attribution (CC BY) license (https:/ / creativecommons.org/licenses/by/ $4.0 /)$.

\author{
International Business and Entrepreneurship, School of Business and Management, \\ Lappeenranta University of Technology, Yliopistonkatu 34, FI-53850 Lappeenranta, Finland; \\ Henri.Hakala@LUT.fi \\ * Correspondence: Iben.Nielsen@student.LUT.fi
}

\begin{abstract}
Circular Economy (CE) and Quality of Life (QoL) are trending topics that have been researched extensively at both the local, regional and global levels. CE is often described as one of the key drivers of sustainability, and sustainability is one of the key drivers of improving QoL. However, studies that investigate the relationships between CE and QoL are rare, and a clear research gap exists. Therefore, this paper aims to initiate this discussion and bring forward illustrative examples on areas where CE could potentially have an impact on QoL, both on an individual and a societal level. By asking the question of how circular business strategies may impact QoL and how they relate, we investigate how CE can influence various aspects of QoL. We utilize the framework consisting of six CE strategies known under the acronym ReSOLVE to discuss how these CE strategies can be leveraged to impact QoL. Our discussion indicates a potential for both environmental and social gains through the implementation of circular product and service solutions. We also suggest that unintended consequences may occur, especially at the societal level. Hence, we propose that, while the discussion on CE has been focused on the environmental aspects of sustainability, the broader implications for QoL and other aspects of sustainability should also be included within the domain of CE implications. Hence, we propose that further research is necessary to develop a framework explaining the relationship between $\mathrm{CE}$ and QoL, encompassing both the positive and negative aspects.
\end{abstract}

Keywords: responsible business practice; circular economy; quality of life; business strategy; sustainability

\section{Introduction}

Businesses play a key role in the transition to $\mathrm{CE}$ whether through pull or push mechanisms initiated by external enablers such as changes to demographics, technology, legislation and other external factors challenging the market equilibrium [1]. Many products and services contributing to a desirable QoL are based on the use of scarce, finite, and virgin raw materials [2]. If current production and consumption levels are maintained, an increase in population and of the global middle class are likely to cause scarce and finite resources to become even scarcer or to be exhausted faster [3,4]. Increased scarcity leads to price increases, and the current linear end-of-life disposal system will continue to waste these resources as the majority are lost forever through incineration or by going to landfills [5].

While many products and services actually improve QoL, the same products and services have also been perceived as reducing QoL by polluting the environment [6], being wasteful [3], and encouraging materialism and over-consumption [7]. The current, predominantly linear, production system is characterized by a unidirectional cradle-tograve approach where raw materials are first extracted, then entered into a process that creates a product, and at the end of its life the product is discarded [8].

With such important topics, a relatively short timeline and the potential for huge impact across the globe we formulated the following question: how may circular business strategies impact QoL and how are they related? 
This paper addresses a recent call to more closely examine the impacts novel business models can have on ecosystems, society and the planet, focusing specifically on the impacts of circular business models on societal aspects and, peripherally, the planet [9]. In this paper, by using illustrative case examples, we will initiate a discussion on how $\mathrm{CE}$, from a business perspective, has the potential to impact QoL. By identifying aspects of QoL that can be affected by a $\mathrm{CE}$, we contribute to the growing literature on the $\mathrm{CE}$ by outlining the micro- and macro-level benefits to collective and individual QoL.

\section{Materials and Framework}

\subsection{Literature Review}

We applied the steps of a systematic review, a four stage model developed for systematic literature reviews in entrepreneurship research [10]. The stages of the systematic literature review followed are (1) planning the review, (2) identifying and evaluating studies, (3) extracting and interpreting data, and (4) dissemination of findings [10]. Figure 1 presents the search criteria for the literature review as well as the number of articles identified during each step.

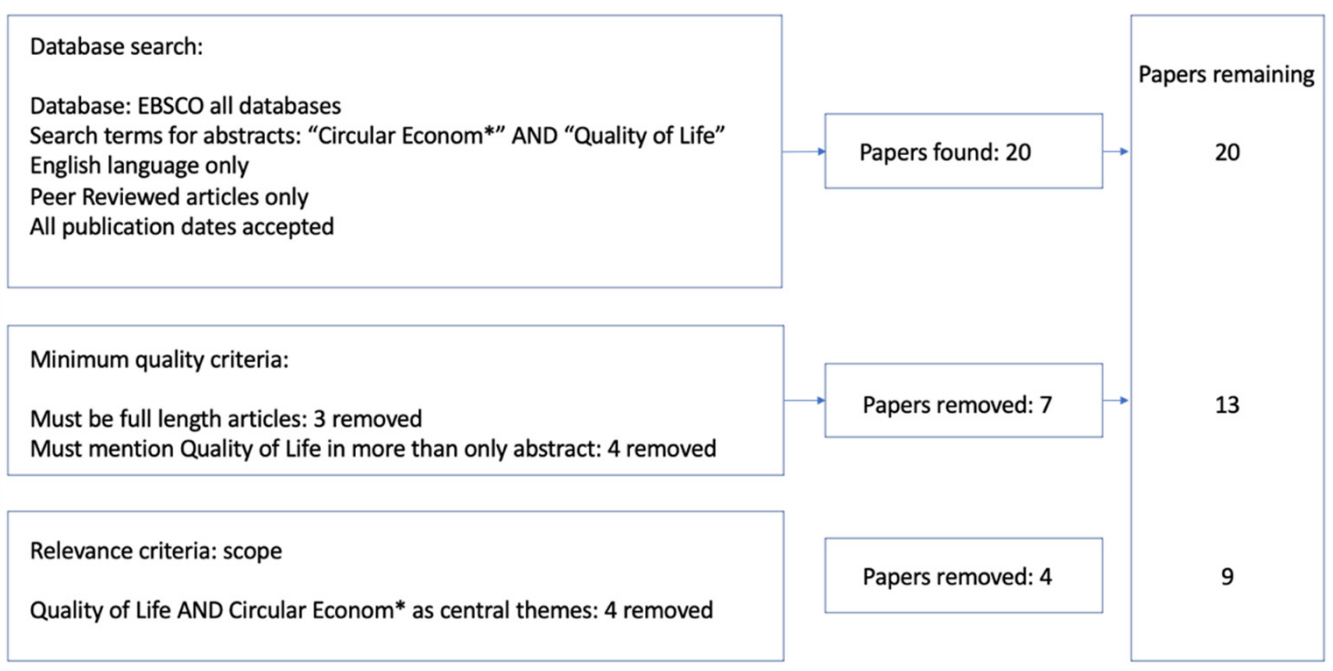

Figure 1. Literature review criteria and results.

We first searched for previous review literature on the relationship between $C E$ and QoL. However, we found none. We defined our search criteria to academic, full text, peer reviewed articles in English where both "Circular Econom" and "Quality of Life" occurred in the abstract. We carefully considered whether to use related search terms and subcategories of both CE and QoL. However, we decided against that approach as our interest specifically was on CE strategies affecting QoL. Furthermore, we decided to exclude articles where QoL was only mentioned in the abstract and not in the body of the article to ensure the search terms were a focus of each article. The literature search was conducted in all EBSCO databases. After excluding articles that did not meet the above criteria, only nine articles remained. The key aspects with regards to CE strategy and QoL in these articles are summarized in Table 1.

\subsection{Descriptive Research Method}

The above steps of a systematic literature review methodology clearly establish the research gap: a lack of studies that explicitly investigate the links between CE and QoL. As there are only a handful of studies on the topic, we decided to complement our literature study by using the descriptive research method with illustrative cases. Descriptive research methods have been applied in multiple areas of research, from management studies [11], to education [12], to nursing [13]. Descriptive research is centered around what is happening, rather than how or why, and describes phenomena and the characteristics of 
the phenomena [12]. Hence, in this qualitative paper we inductively aim to illustrate the potential links between CE and QoL Discussing the potential links between CE and QoL using illustrative examples, we build some fundamental arguments that should encourage further empirical research on the CE-QoL relationship.

Table 1. Overview and analysis of content from the nine journals identified during literature review.

\begin{tabular}{|c|c|c|}
\hline Authors and Article & $\begin{array}{c}\text { CE Strategy } \\
\text { (Regenerate, Share, Optimize, Loop, } \\
\text { Virtualize, Exchange) }\end{array}$ & $\begin{array}{c}\text { QoL Aspects } \\
\text { (Physical, Material, Social, and Emotional } \\
\text { Wellbeing, and Development and Activity) }\end{array}$ \\
\hline $\begin{array}{c}\text { de Oliveira, C. T., Luna, M. M. M., and } \\
\text { Campos, L. M. S. (2019). Understanding the } \\
\text { Brazilian expanded polystyrene supply chain } \\
\text { and its reverse logistics towards } \\
\text { circular economy. }\end{array}$ & $\begin{array}{l}\text { Reverse logistics aim to reduce, reuse and } \\
\text { recycle materials in the polystyrene supply } \\
\text { chain (Loop) }\end{array}$ & $\begin{array}{l}\text { Reverse logistics create material wellbeing } \\
\text { through increased employment }\end{array}$ \\
\hline $\begin{array}{l}\text { Janevski, Z., and Tasheva, V. K. (2019). Circular } \\
\text { Economies Resource Efficiency, Challenges } \\
\text { and Opportunities for “Green” Economy in } \\
\text { North Macedonia. }\end{array}$ & $\begin{array}{l}\text { Waste management and resource efficiency can } \\
\text { be used to transition to an economy to a green } \\
\text { economy (Optimize and Loop) }\end{array}$ & $\begin{array}{l}\text { Waste management and resource efficiency } \\
\text { improves physical and emotional wellbeing by } \\
\text { reducing environmental degradation }\end{array}$ \\
\hline $\begin{array}{l}\text { Fauré, E., Finnveden, G., and } \\
\text { Gunnarsson-Östling, U. (2019). } \\
\text { Four low-carbon futures for a Swedish society } \\
\text { beyond GDP growth. }\end{array}$ & $\begin{array}{l}\text { Consuming immaterial activities, leasing } \\
\text { products instead of purchasing, repairing, } \\
\text { reusing, recycling and closing material loops } \\
\text { are all ways to enable a low carbon future } \\
\text { (Loop and Virtualize) }\end{array}$ & $\begin{array}{c}\text { Reduced carbon emissions improve } \\
\text { environmental health, which improves } \\
\text { physical wellbeing and increased accessibility } \\
\text { to virtual experiences creates } \\
\text { emotional wellbeing }\end{array}$ \\
\hline $\begin{array}{l}\text { Mazzocchi, G., and Marino, D. (2020). Rome, } \\
\text { a Policy without Politics: The Participatory } \\
\text { Process for a Metropolitan Scale Food Policy. }\end{array}$ & $\begin{array}{c}\text { Food policies can improve access to quality } \\
\text { food items by pursuing a zero-waste } \\
\text { objective (Loop) }\end{array}$ & $\begin{array}{l}\text { Quality food improves physical wellbeing and } \\
\text { participatory food policy processes create } \\
\text { space for socialization, combating waste, } \\
\text { fighting social exclusion and discrimination } \\
\text { thereby improving social wellbeing }\end{array}$ \\
\hline $\begin{array}{l}\text { Zając, P., and Avdiushchenko, A. (2020). The } \\
\text { impact of converting waste into resources on } \\
\text { the regional economy, evidence from Poland. }\end{array}$ & $\begin{array}{l}\text { Turning resources into raw materials and } \\
\text { improving resource efficiency can improve } \\
\text { regional economies (Optimize and Loop) }\end{array}$ & $\begin{array}{c}\text { Improved regional economies can create better } \\
\text { income and more jobs, thereby improving } \\
\text { material wellbeing as well as social wellbeing } \\
\text { derived from social integration and the } \\
\text { stimulation of social innovation, positively } \\
\text { affecting physical wellbeing through } \\
\text { improved health }\end{array}$ \\
\hline $\begin{array}{l}\text { Zorpas, A. A. (2020). Strategy development in } \\
\text { the framework of waste management. }\end{array}$ & $\begin{array}{c}\text { Appropriate and ambitious waste } \\
\text { management strategies enable and accelerates } \\
\text { the circular economy and reduces carbon } \\
\text { emissions (Optimize and Loop) }\end{array}$ & $\begin{array}{c}\text { Effects on QoL are not explicitly discussed in } \\
\text { the article, but less waste is likely to improve } \\
\text { environmental health and hence } \\
\text { physical wellbeing }\end{array}$ \\
\hline $\begin{array}{l}\text { Manea, D.-I., Istudor, N., Dinu, V., and } \\
\text { Paraschiv, D.-M. (2021). Circular Economy and } \\
\text { Innovative Entrepreneurship, Prerequisites for } \\
\text { Social Progress. }\end{array}$ & $\begin{array}{c}\text { Circular economy, digital innovation and } \\
\text { sustainable entrepreneurship influence social } \\
\text { progress by sharing resources and using them } \\
\text { efficiently (Loop and Share) }\end{array}$ & $\begin{array}{l}\text { Social progress improves material wellbeing } \\
\text { through economic growth, and by reducing } \\
\text { pollution, physical wellbeing is improved, } \\
\text { increased accessibility to education improves } \\
\text { development and activity, and lower crime } \\
\text { rates improve social wellbeing }\end{array}$ \\
\hline $\begin{array}{l}\text { Barcelos, S. M. B. D., Salvador, R., Barros, M. V., } \\
\text { de Francisco, A. C., and Guedes, G. (2021). } \\
\text { Circularity of Brazilian silk: Promoting } \\
\text { a circular bioeconomy in the production of } \\
\text { silk cocoons. }\end{array}$ & $\begin{array}{l}\text { Reducing waste and channeling organic } \\
\text { materials through a biodigester ensures less } \\
\text { pollution and waste generation while creating } \\
\text { value added renewable energy products } \\
\text { (Regenerate and Loop) }\end{array}$ & $\begin{array}{c}\text { Improved environmental health improved } \\
\text { physical wellbeing, and value adding activities } \\
\text { improve material wellbeing }\end{array}$ \\
\hline $\begin{array}{l}\text { Cuomo, F., Lambiase, N., and Castagna, A. } \\
\text { (2021). Living lab on sharing and circular } \\
\text { economy: The case of Turin. }\end{array}$ & $\begin{array}{l}\text { Living Labs encourage innovation addressing } \\
\text { climate, environmental and health challenges } \\
\text { exemplified through reusing resources (Loop) }\end{array}$ & $\begin{array}{c}\text { Effects on QoL are not explicitly discussed in } \\
\text { the article, but collaboration is likely to } \\
\text { improve social wellbeing }\end{array}$ \\
\hline
\end{tabular}

\subsection{Frameworks and Definitions}

QoL has both objective and subjective aspects [14]. Subjective QoL dimensions are contextual and personal [15], and will not be addressed here as we seek to tie general QoL aspects to Circular Business Strategies. The objective dimensions can be divided into five categories: (1) physical wellbeing, (2) material wellbeing, (3) social wellbeing, (4) development and activity, and (5) emotional wellbeing [14]. QoL can, furthermore, be divided into three systemic levels, from the individual level, through the program level, to the societal level [16]. 
The concept of a CE has been proposed as a systemic economic and material shift towards enabling meeting the needs of future generations as well as those of our own. A CE seeks to transform the system of how and what we consume without compromising our collective QoL by decoupling economic growth from environmental depletion [17]. A CE can be defined as "a regenerative system in which resource input and waste, emissions, and energy leakage are minimized by slowing, closing, and narrowing material and energy loops" [18], although a variety of definitions have been proposed over time and with varying foci [19].

The CE strategy creating the framework for this discussion paper is the ReSOLVE framework which has been adopted also by many academic researchers after the Ellen MacArthur Foundation first launched it. ReSOLVE is an acronym of six CE strategies: Regenerate, Share, Optimize, Loop, Virtualize and Exchange [20].

Each of these strategies are discussed first theoretically and then discussed with examples linking them to aspects of QoL in the following discussion section.

\section{Discussion}

The discussion follows the structure of the six CE business strategies. In each section, we first theoretically explain each CE strategy and thereafter showcase illustrative examples and discuss the relationship with specific aspects of QoL.

\subsection{Regeneration}

The novelty of the regeneration aspect of a CE is the positive connotation of actively engaging and interacting with the environment [21]. Drawing on living systems thinking, regenerative design seeks to understand the interaction and complex relationship between things within specific contexts [22]. Regenerative business strategies challenge conventional businesses to become restorative and enhance all forms of life rather than to degrade and exploit ecological systems [23]. While reducing harmful impacts and searching for solutions with neutral impacts is the aim of sustainable development [21], regeneration instead actively seeks to improve or restore. Therefore, not only should non-renewable resources be avoided, but renewable resources should, additionally, be preserved or enhanced by design. Regenerative design principles favor synergistic and holistic approaches more than fragmented and sub-optimized parts and processes [22]. The implementation of any regenerative action is highly contextual, and is not about one-size-fits-all solutions because the place and context determine what actions improve the action [22].

None of the nine articles identified during the literature review focused on the regenerative aspect of CE business strategies.

Examples of industries where regenerative strategies have been implemented successfully include agriculture, the energy sector, and the construction industry. Regenerative and restorative agriculture aims to improve local soil, water, biodiversity and ecosystem health, and carbon sequestration [24]. It targets the societal level of QoL through improvements in the environment. Moreover, regenerative agriculture often requires more on-site laborers than conventional farming, which on an individual level, enhances job prospects, interpersonal relationships, and community involvement [25] and on a societal level may also affect local or regional material and social wellbeing and aspects of development and activity. The increased use of shelterbelts, hedges and other native perennials creates a space and habitat for wildlife [24] and thereby increases the recreational value of farming areas. The improved natural habitat may also provide a basis for businesses providing services that utilize the outdoors, providing yet more social benefits from regenerative farming.

Regenerative actions in the energy sector are mostly about the use of renewable energy sources and include biomass, hydropower, geothermal, solar, wind, and marine energy [26]. The benefits include reduced emissions from fossil fuels [26], de-centralized energy production [27], and the creation of jobs, economic growth, and energy security [28]. This has also created specialized supply chains, finance, maintenance, and consulting sectors, providing jobs, subsequent development, and enhancing material wellbeing, while 
the de-centralization of energy production supports energy security and contributes to safer societies.

Regeneration in the construction industry includes examples such as green roofs. Green roofs are vegetated according to the local climate and have several benefits at both the individual and societal levels, including stormwater retention and cleaning, thermal benefits, energy savings, cleaner air, improved aesthetics, and the greening of urban outdoor space [29]. Designing and constructing green roofs adds to a regenerative and restorative built environment, and green roofs can be integrated with solar energy units to provide electric power for a building.

Regenerative business opportunities can be created in both old and new industries. Regeneration and restoration will not only mitigate negative outcomes but should produce a net positive outcome for all living things, particularly in respect of physical wellbeing. SMEs may more easily adapt and adopt these strategies whereas larger enterprises may have to undergo more significant changes to adjust to regenerative strategies. Regeneration, as emphasized above, should be seen in context, and the concept is often closely connected to the looping and exchange strategies (as explained later in this chapter) to further enhance the overall impact.

\subsection{Share}

The sharing of assets is not new. However, the extent and market potential of the sharing economy is [30], and it appears to be a continuously growing market as new types of assets become shareable. By challenging the notion of ownership, the sharing economy seeks to reduce the total number of products produced and in use by shifting focus to the accessibility of the resources. Business models supporting the sharing economy can be divided into three types: the access economy, the platform economy, and the communitybased economy [31], and sharing can occur either sequentially or simultaneously [32]. The access economy optimizes usage by eliminating underutilization and idle time [30], whereas the platform economy is a digital and decentralized exchange of assets, products, and services among its users, and the community-based economy involves informal interaction initiatives to contribute to a specific community [31]. The ideas of the sharing economy are applicable to both the business-to-business and the business-to-consumer markets [33]. Research has suggested that businesses can adapt to the sharing economy in at least six distinct ways: (1) selling the right to use instead of ownership, (2) supporting customers in reselling products, (3) exploiting unused resources, (4) providing repair and maintenance services, (5) targeting new customers and (6) by developing novel business models that utilize the idea of sharing in other, still unknown, ways [34].

Sharing as a CE business strategy was mentioned in one of the nine articles identified during the literature review and exemplified through sequential reuse where $C E$ is described as a prerequisite for social progress [35].

Examples of industries where sharing strategies have been implemented successfully include car sharing, clothes rental and second-hand sales, and home sharing. Clothes sharing is an example of sequential sharing that maximizes the utilization of clothes before their end of life while providing customers with an ever-changing, fashionable wardrobe. Some clothing companies have extended their business models to allow customers to rent; customers choose which garments to rent, receive them by mail, wear them, and return them by mail. The clothes provider cleans them, then rents out the clothes to the next customer in line. On an individual level, the customer benefits from access to new outfits for less than the retail price, which affects the emotional and material wellbeing aspects of QoL. On a societal level, the company can rent out the clothes sequentially and repeatedly to minimize the environmental impact associated with their production and disposal. The downside is an increased need for logistics, potentially realized by fossil fuel powered vehicles.

Car sharing exemplifies simultaneous sharing in the access economy which provides demand-based transportation solutions to customers. The business models differ among 
providers of car sharing services. For the customer, conveniently, fuel, insurance, and maintenance are included in the price, and there is no large upfront investment or down payment of a car purchase. Even though the customer can include car preferences in the car sharing service, the customer sacrifices input into the individual style, color, and model of car they use, and may have to book the car in advance. Car sharing can also occur through informal sharing schemes where drivers and passengers connect via a digital platform and agree on a time, place, and price. The car sharing service provider receives a steady cash flow from monthly subscriptions or for direct use. Individuals using car sharing services are often motivated by value-seeking, convenience, lifestyle, and environmental concerns [36]. Car sharing targets the societal level of QoL through the reduced material consumption of raw materials for production by reducing the need for privately owned cars. At the same time, car sharing also addresses the material wellbeing aspect of QoL by providing accessibility to a car when needed, as well as the emotional wellbeing aspects by being part of the consumption solution rather than problem.

Home sharing is a sequentially sharing platform economy where homeowners rent out space in their property. Digital home sharing platforms are monetized via charges to both host and customer, although setting up the account and listing the home on a digital platform often is free. For the individual, the QoL is enhanced through material wellbeing in the form of additional income for the host and social or material wellbeing for the customer through unique accommodation options. However, on the societal level, disadvantages also exist and include the potential of tourist gentrification, social imbalances and increased rental prices [37]. This may counteract some of the environmental benefits the sharing economy targets.

Nevertheless, renting, sharing and pooling resources can significantly reduce the environmental impact of some product groups [32]. The corollary is that people tend to handle products they do not own with less care than their own possessions, meaning shared or rented products might be exchanged before their technical end of life [32], which would reduce the environmental benefits. Furthermore, for car sharing, the environmental benefits are difficult to document since up to $80 \%$ of the environmental impact is generated during the use of the car, through fuel consumption, rather than during production [38]. Nevertheless, fewer cars produced in total means fewer parking spaces are necessary and thus less built environment to accommodate vehicles is needed. The sharing economy can stimulate over-consumption because the money saved or earned through sharing of products can be utilized to share or purchase items that individuals would not otherwise have been able to afford [39], although the financial benefits of sharing can also be used to purchase higher quality or more efficient products [32].

\subsection{Optimize}

The optimization and improvement of resource efficiency is an established business practice to increase profitability. However, it is not only resources that should be optimized in a CE. So, too, should products and processes. Optimization in CE utilizes the notion of designing out waste and pollution, where companies (re)design processes and products to eliminate waste throughout the both production process and the products' lifetime [40]. One way of optimizing a production system is through the lean enterprise ideal, where the focus on value is extended to encompass the entire supply chain [41]. Furthermore, new technology can help by encouraging leaps in process and product optimization [42], for example by utilizing big data, sensors, or automation technologies. Optimization can occur in both internal processes, such as lean manufacturing [41] and external processes, like industrial symbiosis [43]. Optimizing product performance targets increased durability to retain the product in use, whether it is through improved durability, modular design, or upgradability.

Optimization is a CE business strategy mentioned in several of the nine articles identified during the literature review, all exemplified through waste management research 
and sometimes closely tied to the CE business strategy Loop. One article discussed the CE optimization of resource efficiency to enable a Green Economy [44].

Examples of industries where optimization strategies have successfully been implemented include the manufacturing industry and urban infrastructure design. Lean manufacturing pursues perfection through the notion of continuous improvement and is based on the use of certain principles, tools, and techniques [45]. By identifying and eliminating waste, and by only engaging in processes that bring value to the customer, manufacturing plants have achieved a flexible and reliable manufacturing system within which flow matches demand, and that has reduced costs [45]. Benefits include flexibility and a cost reduction-oriented manufacturing plant. Customers benefit for example; from individualized mass-produced cars at affordable prices, which can enhance material and emotional wellbeing, and moreover, they also benefit from the environmental benefits of the reduced use of resources, machinery, and raw materials.

Smart urban design has the potential to significantly reduce the environmental impact of the built environment, and the transportation of people and goods and has seen a surge in application in recent years. Smart urban mobility relates to the affordable, effective, attractive and sustainable connectivity of and between people, goods, services, and opportunities [46]. Through urban design, optimized urban mobility patterns can encourage a shift from motorized mobility to pedestrian- and cycling-friendly connectivity. Attention to smart city design can support innovation, urban growth, and QoL through specific policies improving green infrastructure, inclusiveness, housing, mobility, and science and technology [47]. Transforming the urban living experience through urban greening, sustainable mobility, increased public space, and citizen participation [48] addresses the social wellbeing as well as the development and activity aspects of QoL. Despite these benefits, such transformational land use designs can be met with challenges from citizens who do not agree with, or desire, such new developments [48].

The novelty of optimization from a CE perspective is the focus on holistic optimization. That is, optimization along the entire value chain rather than at individual company level, or of a whole company rather than individual processes or product lines: the aim is thus to do more with less.

\subsection{Loop}

Looping refers to the continuous circulation of materials. By looping materials, valuable resource inputs are created from what has traditionally been considered waste [49]. Two different types of loops can be identified: the technical and the biological [50]. The aim of the technical loop is to repeatedly loop non-biodegradable materials and thus to keep the materials circulating, while the aim of the biological loop is to return renewable materials to the earth as nutrients [51]. The loops are considered hierarchical, and the technical loop suggests that remanufacturing should be prioritized before recycling to capture the higher value of any given material at any given time. Following this logic of preserving value, sharing, repairing, and reusing are placed higher in the hierarchy than remanufacturing and recycling [50]. Furthermore, loops can be divided into closed-loop systems where the material is used within the same company or industry, and an open-loop system where the material is utilized in a different industry [49]. The loops apply to all scales from local to global, and thus reverse logistics must be considered to find the optimal way to loop materials [52]. Turning waste into raw materials not only reduces the amount of material going to landfills, it also reduces the need to extract virgin raw materials [53].

Some case studies have shown that the energy consumption needed to turn waste into raw materials can be less than the energy consumption associated with extracting virgin raw materials [54]. Remanufacturing and recycling are well-known examples of resource loops. However, looping materials is intricately linked to designing products to allow for disassembly and reducing the number of different materials used in each product.

Looping materials is a $\mathrm{CE}$ business strategy mentioned in eight of the nine articles identified during the literature review, exemplified through multiple foci including ambi- 
tious waste management strategies [55], reverse logistics [56], zero-waste objectives [57] and raw material input [58].

Examples of looping resources that have been successfully implemented include carpet manufacturers, beverage packaging deposit systems, and the recycling and remanufacturing industries. The commercial carpet industry has been able to close the loop due to a technological development that enabled more efficient separation of the carpet tile components at the end of the carpet's life, so the carpet fibers and backing materials could be extracted cleanly and inserted back into carpet production as raw material of the same grade as it was originally [59]. Another key enabler for closing the loop was close partnerships with chemical companies that could re-melt the nylon into new nylon carpet fibers, and a reclamation program set up to take back used carpet tiles from the customers [59]. Furthermore, the introduction of a leasing business model encouraged the return of carpet tiles [60] and added another aspect to the circularity of the carpet industry. The societal benefits of avoiding putting used carpet tiles into landfills are compounded by the benefits of the reduced need for virgin raw materials in the production of new carpets. The customer benefits mainly address the emotional aspects of QoL derived from the fact that their choices reduce the environmental burden although both material and physical wellbeing also could be relevant depending on the price level and chemical compounds of the carpet tiles.

The recycling and remanufacturing industries are, from a CE hierarchy perspective, the last option for a product because of the associated environmental benefits moving down the $C E$ hierarchy [61]. Mechanical and chemical recycling are also established industries, yet the efficient and highest quality outcome of recycling requires reverse logistics, ease of disassembly, supportive legislation and a certain level of knowledge from the customer side [56].

One closed loop subcategory of the recycling infrastructure consists of deposit-refund schemes where reusable packaging, such as beverage packaging, is returned through incentivized schemes to reduce the amount of virgin raw material for packaging use, and bottle deposit systems that utilize the use, return, wash, and reuse cycle [62]. Such schemes take different forms, yet tend to face similar challenges across countries and schemes, including collection, eco-design and the profitability of the business model [62].

To fully embrace a CE and reap the benefits to society, it is crucial to move from thinking about waste and waste handling to considering material handling throughout the lifecycle of products, including the quantification of processes such as disassembly since the ease of disassembly will impact the financial viability of a CE [63]. Products and assets should be shared, reused, and repaired before they go to remanufacturing and recycling plants at the end of their useful life. Whether companies pursue closed- or open-loop systems will depend on external factors such as regulations, logistics, customer relationships, and costs.

\subsection{Virtualize}

The virtualization of products, processes and utilities has been made possible by technological development. Virtualization reduces the need for physical consumption and production yet may deliver a similar customer experience through virtual consumption [64] Through dematerialization and digitization, the reduction of material consumption is facilitated [65] by accessing and using products through online platforms. Virtualized product offerings not only make physical products redundant, but also increase accessibility and reduce the need for transportation, storage, archiving, and safekeeping. Interestingly, the move to virtual consumption can be underpinned by material goods [64] and has sparked increased customer demand for equipment enabling the virtualization [66].

Virtualization as a CE strategy was mentioned in one of the nine articles identified during the literature review, an article proposing ways to create a low carbon future in which consuming cultural offerings and shifting to leasing rather than buying products are key [67]. 
Examples of industries where virtualization strategies have successfully been implemented include e-book and music streaming, remote work, and online education. E-book and music streaming are a digitized service of everyday product offerings that used to require the printing of books and the manufacture of CDs, cassette tapes, or vinyl records. Anyone with access to the internet and a computer or smartphone can now register, purchase and download the desired books or songs or albums, enabling instant and continuous access to the content. Mass-digitization has also made literature more accessible by offering audiobooks to serve the needs of people living with disabilities, small children, and commuters. Societal benefits include fewer greenhouse gas emissions through the reduction in transportation which is compounded by the reduced need for virgin raw material extraction and processing. The QoL is enhanced by cost savings and subsequent material wellbeing, in addition to the physical wellbeing from the reduced environmental degradation.

Telecommuting, or remote working, has been steadily increasing alongside technological advances [68] is increasingly an option for employees, can take different forms, including part time or full time, regular, or flexibly scheduled, and can be used for local and international meetings and conferences. The societal benefits of remote working can include reduced traffic congestion, socially inclusive work environments for vulnerable groups and minorities, organizational cost savings, increased productivity [69], and reduced fuel consumption occasioned by commuting. The individual benefits range from emotional wellbeing, to development and activity aspects including work-life balance and flexibility, to physical wellbeing prompted by spending less time commuting [70]. However, remote working can also adversely affect social wellbeing, owing to the absence of collegial interaction and after-work social activity.

Massive Open Online Courses (MOOCs) have made university-level education widely accessible either free of charge or for a small fee in exchange for a certificate of completion [71]. Although MOOCs differ, they are generally simpler than traditional university courses, impersonal, can be completed without supervision, might have few if any entry requirements, and rely on peer-to-peer feedback [72]. Online education through a MOOC can especially benefit individuals lacking the financial means to attend traditional universities, or who live in rural areas, or who are particularly time constrained. In addition, individuals with an initial interest in a certain topic also benefit from MOOCs because they are easily accessible, and the wide variety of courses offered is not limited to a certain school or place. On a societal level, education and knowledge benefit people in multiple ways, including enhancing emotional and social wellbeing and in terms of development and activity aspects such as competence development, job support, and productivity.

Although virtualization or dematerialization reduce the need for certain physical products, there has been a trend to increase the volume of electronic assets that make virtualization possible [66]. Not everything can be substituted by a virtual experience, and meeting people in real life will continue to be important for social and emotional wellbeing. Nevertheless, virtualization, where possible and convenient, still offers considerable future potential.

\subsection{Exchange}

The exchange CE strategy focuses on replacing old materials, technologies, and products with new and advanced solutions that are better for the environment [50]. Material or resource exchange can be either a direct or an indirect substitute with better performing qualities or can create a new solution that still fulfills essential customer needs. As such, exchange strategies demand little from customers but a lot from materials and/or technology development, as the substitute materials often need to fit with the existing system of production in order to achieve acceptance and offer economic viability as direct substitutes [20].

Exchanging old materials for new ones is a CE strategy that was not mentioned in the nine articles identified during the literature review.

Examples of industries where exchange strategies have been implemented successfully include fashion, packaging, and biotech. Fashion items are being made from marine 
plastic waste collected and recycled into high performing yarn [73] although yet far from mainstream. The societal QoL benefits includes an improved environment through the action of removing plastic bound for oceans and economically by creating value from waste. QoL aspects for individuals are mainly generated through the emotional wellbeing of positive affect, respect, satisfaction, and fulfillment.

Firms have developed biodegradable and renewable packaging material from seaweed [74], and new materials are continuously being discovered, as well as ways to replace traditional materials with these new ones. The QoL on a societal level is improved through the elimination of non-recyclable packaging and the production and consumption of single use plastic cups, as well as regeneratively by de-acidifying the oceans through seaweed removal. The QoL for individuals is improved through the emotional wellbeing arising from positive affect and satisfaction. Moreover, the biotech industry has developed new materials to replace a range of less sustainable materials.

Societal QoL improvements stem from the natural ingredient and biodegradable output that reduces fossil fuel raw materials and enables biological looping at the end of its life. The QoL is improved by way of the individual's emotional wellbeing through positive affect and satisfaction.

The exchange and replace business opportunities continuously change as new developments come along and discoveries are made in the realms of materials, applications, and technology. Exchanging materials and technologies for new ones is not new for incumbent firms and it can be a lengthy process where due diligence ensures that specific quality, safety, and standards are met. The novelty of the CE approach to exchanging materials and technologies is encapsulated in the nature, qualities, and abilities of the new materials and technologies.

\section{Concluding Remarks}

This paper intended to bring forward and illustrate some of the links between CE business strategies and various aspects of QoL to warrant further research and the exploration of the potential for developing theory on this topic. We have illustrated how CE can be a driver of value creation, not just for environmental benefits, but also more broadly on aspects of QoL. The adage "bigger is better" is well known and has ruled production and consumption for some time, yet with the potential for improvements in QoL a CE rather dictates a "circular is better" business approach. Taking steps to design more circularity into production-consumption systems have been suggested as an environmentally and financially sustainable basis for successful business. However, there is little research about the QoL aspects of CE. While our examples imply that CE might have implications also for QoL, the key point is that we should learn more about this relationship, how external enablers impact the transition to $\mathrm{CE}$, and how QoL intertwines with the environmental and economic pillars of sustainability.

The lack of prior empirical research identified already by the systematic review on the topic highlights the need for further research investigating the links between CE and QoL. Only four of the six CE strategies (Share, Optimize, Loop, and Virtualize), were mentioned in articles identified during the literature review. Neither Regenerate nor Exchange were addressed at all, despite all nine articles having been published since 2019 and thus within the timeframe of all six CE strategies. However, all the different aspects of QoL were implied, either as explicit or implicit benefits of $C E$ strategies. We could extract very little actual empirical evidence on the mechanisms or effects of the CE strategies, highlighting the need to continue with empirical examinations and theory building on the links between $\mathrm{CE}$ and quality of life.

Based on our exploration of illustrative cases, we propose that the effect of $\mathrm{CE}$ on QoL may be achieved most rapidly if businesses implement initiatives addressing many of the above categories. Implementing strategies from just one or two of the categories will not make a company circular, but could still be a start on a worthy path and have positive implications for some aspects of QoL It is important to remember that circularity is 
a holistic approach and that full circularity may be an idealistic aspiration. Nevertheless, this type of approach helps to balance the positives and the negatives in any systemic and strategic change. Ideally, in the future, products would first be produced with renewable energy and from renewable raw materials and with regenerative or restorative features. Second, the products should be optimized for long term use and disassembly and produced in an optimized supply chain. Third, the products should be shared throughout their useful life, before entering the remanufacturing and recycling loops to create new material inputs. Where feasible, products should be virtual, and thus some of the former steps would become redundant. Lastly, materials and technologies should be exchanged for new, advanced materials and technologies that continuously emerge.

In the broader sense, our discussion above of the effect of a CE on QoL contributes by helping to move the discussion away from the focus on purely environmental benefits that has dominated to date, towards the social sustainability aspects of the CE. However, CE strategies also have the potential to reduce QoL for some at the same time as they bring environmental benefits. Therefore, this discussion also might bring forward the tradeoffs between environmental and social sustainability. We suspect that the greatest societal benefits for QoL do take effect through the environmental aspects of reduced pollution, fossil fuel dependency, greenhouse gas emissions, and energy consumption. Environmental health is vital to all living things, and we depend on the world to live our lives and conduct our business, yet the $\mathrm{CE}$ also has the potential to make a significant positive impact directly on individuals' QoL.

Future research could be based in a wide variety of research traditions. Sustainable entrepreneurship could be an interesting starting point because it is a research field encompassing both the social and environmental aspects of entrepreneurship [75], focused on innovations benefitting the society at large [76] and it therefore may be a good basis for studying the interconnectedness of QoL and CE.

Author Contributions: Conceptualization, I.B.N.; methodology, I.B.N.; software, I.B.N.; formal analysis, and investigation, I.B.N.; resources, I.B.N. and H.H.; writing-original draft preparation, I.B.N.; writing-review and editing, I.B.N. and H.H.; supervision, H.H. All authors have read and agreed to the published version of the manuscript.

Funding: We would like to acknowledge the financial support from Package-Heroes project (no. 320217) funded by the Strategic Research Council at the Academy of Finland.

Institutional Review Board Statement: Not applicable.

Informed Consent Statement: Not applicable.

Data Availability Statement: Not applicable.

Conflicts of Interest: The authors declare no conflict of interest.

\section{References}

1. Davidsson, P.; Christof, J.; Briel, V. External Enablement of New Venture Creation: A. Framework. Acad. Manag. Perspect. 2018, 34, 311-332. [CrossRef]

2. Whicher, A.; Harris, C.; Beverley, K.; Swiatek, P. Design for circular economy: Developing an action plan for Scotland. J. Clean. Prod. 2018, 172, 3237-3248. [CrossRef]

3. Kopnina, H. Green-washing or best case practices? Using circular economy and Cradle to Cradle case studies in business education. J. Clean. Prod. 2019, 219, 613-621. [CrossRef]

4. George, D.A.R.; Lin, B.C.A.; Chen, Y. A circular economy model of economic growth. Environ. Model. Softw. 2015, 73, 60-63. [CrossRef]

5. Ghisellini, P.; Cialani, C.; Ulgiati, S. A review on circular economy: The expected transition to a balanced interplay of environmental and economic systems. J. Clean. Prod. 2016, 114, 11-32. [CrossRef]

6. Perera, F. Pollution from fossil-fuel combustion is the leading environmental threat to global pediatric health and equity: Solutions exist. Int. J. Environ. Res. Public Health 2018, 15, 16. [CrossRef]

7. Lazell, J.; Magrizos, S.; Carrigan, M. Over-claiming the circular economy: The missing dimensions. Soc. Bus. 2018, 8, 103-114. [CrossRef] 
8. Merli, R.; Preziosi, M.; Acampora, A. How do scholars approach the circular economy? A systematic literature review. J. Clean. Prod. 2018, 178, 703-722. [CrossRef]

9. Snihur, Y.; Bocken, N. A call for action: The impact of business model innovation on business ecosystems, society, and planet. Long Range Plan. 2022, 102182, in press. [CrossRef]

10. Kraus, S.; Breier, M.; Dasí-Rodríguez, S. The art of crafting a systematic literature review in entrepreneurship research. Int. Entrep. Manag. J. 2020, 16, 1023-1042. [CrossRef]

11. Jones, O.; Gatrell, C. Editorial: The Future of Writing and Reviewing for IJMR. Int. J. Manag. Rev. 2014, 16, 249-264. [CrossRef]

12. Nassaji, H. Qualitative and descriptive research: Data type versus data analysis. Lang. Teach. Res. 2015, 19, 129-132. [CrossRef]

13. Magilvy, J.K.; Thomas, E. A first qualitative project: Qualitative descriptive design for novice Researchers: Scientific inquiry. J. Spec. Pediatr. Nurs. 2009, 14, 298-300. [CrossRef]

14. Felce, D.; Perry, J. Quality of Life: Its Definition and Measurement. Res. Dev. Disabil. 1995, 16, 51-74. [CrossRef]

15. Saxena, S.; Carlson, D.; Billington, R.; Orley, J.; World Health Organisation Quality of Life Group. The WHO quality of life assessment instrument (WHOQOL-Bref): The importance of its items for cross-cultural research. Qual. Life Res. 2001, 10, 711-721. [CrossRef]

16. Schalock, R.L.; Verdugo, M.A.; Jenaro, C.; Lachapelle, Y. Cross-Cultural Study of Quality of Life Indicators. Am. J. Ment. Retard. 2005, 110, 298-311. [CrossRef]

17. Veleva, V.; Bodkin, G. Corporate-entrepreneur collaborations to advance a circular economy. J. Clean. Prod. 2018, 188, 20-37. [CrossRef]

18. Geissdoerfer, M.; Savaget, P.; Bocken, N.M.P.; Hultink, E.J. The Circular Economy-A new sustainability paradigm? J. Clean. Prod. 2017, 143, 757-768. [CrossRef]

19. Kirchherr, J.; Reike, D.; Hekkert, M. Conceptualizing the circular economy: An analysis of 114 definitions. Resour. Conserv. Recycl. 2017, 127, 221-232. [CrossRef]

20. Ellen MacArthur Foundation. Potential for Denmark as a Circular Economy a Case Study from: Delivering the Circular EconomyA Toolkit for Policy Makers; Ellen MacArthur Foundation: Cowes, UK, 2014; pp. 1-134.

21. Reed, B. Shifting from 'sustainability' to regeneration Forum Shifting from 'sustainability' to regeneration. Build. Res. Inf. 2007, 35, 674-680. [CrossRef]

22. Cole, R.J. Transitioning from green to regenerative design. Build. Res. Inf. 2012, 40, 39-53. [CrossRef]

23. Cole, R.J. Regenerative design and development: Current theory and practice. Build. Res. Inf. 2012, 40, 1-6. [CrossRef]

24. Elevitch, C.R.; Mazaroli, D.N.; Ragone, D. Agroforestry Standards for Regenerative Agriculture. Sustainability 2018, 10, 3337. [CrossRef]

25. Pearson, C.J. Regenerative, Semiclosed Systems: A Priority for Twenty-First-Century Agriculture. Biosci. Mag. 2007, 57, 409-418. [CrossRef]

26. Amponsah, N.Y.; Troldborg, M.; Kington, B.; Aalders, I.; Hough, R.L. Greenhouse gas emissions from renewable energy sources: A review of lifecycle considerations. Renew. Sustain. Energy Rev. 2014, 39, 461-475. [CrossRef]

27. Sperling, K.; Hvelplund, F.; Mathiesen, B.V. Centralisation and decentralisation in strategic municipal energy planning in Denmark. Energy Policy 2011, 39, 1338-1351. [CrossRef]

28. Llera, E.; Scarpellini, S.; Aranda, A.; Zabalza, I. Forecasting job creation from renewable energy deployment through a value-chain approach. Renew. Sustain. Energy Rev. 2013, 21, 262-271. [CrossRef]

29. Shafique, M.; Kim, R.; Rafiq, M. Green roof benefits, opportunities and challenges-A review. Renew. Sustain. Energy Rev. 2018, 90, 757-773. [CrossRef]

30. Belk, R. You are what you can access: Sharing and collaborative consumption online. J. Bus. Res. 2014, 67, 1595-1600. [CrossRef]

31. Acquier, A.; Daudigeos, T.; Pinkse, J. Promises and paradoxes of the sharing economy: An organizing framework. Technol. Forecast. Soc. Chang. 2017, 125, 1-10. [CrossRef]

32. Tukker, A. Product services for a resource-efficient and circular economy-A review. J. Clean. Prod. 2015, 97, 76-91. [CrossRef]

33. Muñoz, P.; Cohen, B. Mapping out the sharing economy: A configurational approach to sharing business modeling. Technol. Forecast. Soc. Chang. 2017, 125, 21-37. [CrossRef]

34. Matzler, K.; Veider, V.; Kathan, W. Adapting to the Sharing Economy About the Research. MIT Sloan Manag. Rev. 2015, 56, 71-77.

35. Manea, D.I.; Istudor, N.; Dinu, V.; Paraschiv, D.M. Circular economy and innovative entrepreneurship, prerequisites for social progress. J. Bus. Econ. Manag. 2021, 22, 1342-1359. [CrossRef]

36. Schaefers, T. Exploring carsharing usage motives: A hierarchical means-end chain analysis. Transp. Res. Part A 2013, 47,69-77. [CrossRef]

37. Garcia-Ayllon, S. Urban Transformations as an Indicator of Unsustainability in the P2P Mass Tourism Phenomenon: The Airbnb Case in Spain through Three Case Studies. Sustainability 2018, 10, 2933. [CrossRef]

38. Scheepens, A.E.; Vogtländer, J.G.; Brezet, J.C. Two life cycle assessment (LCA) based methods to analyse and design complex (regional) circular economy systems. Case: Making water tourism more sustainable. J. Clean. Prod. 2016, 114, 257-268. [CrossRef]

39. Richardson, L. Performing the sharing economy. Geoforum 2015, 67, 121-129. [CrossRef]

40. Ellen MacArthur Foundation. Universal Circular Economy Policy Goals; Ellen MacArthur Foundation: Cowes, UK, 2021.

41. Womack, J.P.; Jones, D.T. From lean production to the lean enterprise. Harv. Bus. Rev. 1994, 72, 93-103. 
42. De Sousa Jabbour, A.B.L.; Jabbour, C.J.C.; Godinho Filho, M.; Roubaud, D. Industry 4.0 and the circular economy: A proposed research agenda and original roadmap for sustainable operations. Ann. Oper. Res. 2018, 270, 273-286. [CrossRef]

43. Rosa, P.; Sassanelli, C.; Terzi, S. Towards Circular Business Models: A systematic literature review on classification frameworks and archetypes. J. Clean. Prod. 2019, 236, 117696. [CrossRef]

44. Janevski, Z. Circular Economies Resource Efficiency, Challenges and Opportunities for 'Green' Economy in North Macedonia. Econ. Dev. 2019, 1, 49-62.

45. Womack, J.P.; Jones, D.T.; Roos, D. The Machine That Changed the World: The Story of Lean Production; Free Press: New York, NY, USA, 2007.

46. Lyons, G. Getting smart about urban mobility-Aligning the paradigms of smart and sustainable. Transp. Res. Part A 2018, 115, 4-14. [CrossRef]

47. Bakici, T.; Almirall, E.; Wareham, J. A Smart City Initiative: The Case Of Barcelona. J. Knowl. Econ. 2013, 4, 135-148. [CrossRef]

48. Zografos, C.; Klause, K.A.; Connolly, J.J.T.; Anguelovski, I. The everyday politics of urban transformational adaptation: Struggles for authority and the Barcelona superblock project. Cities 2020, 99, 102613. [CrossRef]

49. Deschamps, J.; Simon, B.; Tagnit-Hamou, A.; Amor, B. Is open-loop recycling the lowest preference in a circular economy? Answering through LCA of glass powder in concrete. J. Clean. Prod. 2018, 185, 14-22. [CrossRef]

50. Ellen MacArthur Foundation. Growth Within: A Circular Economy Vision for a Competitive Europe; Ellen MacArthur Foundation: Cowes, UK, 2015.

51. Ellen MacArthur Foundation. Towards the Circular Economy: Opportunities for the Consumer Goods Sector; Ellen MacArthur Foundation: Cowes, UK, 2013; pp. 1-112.

52. Kalverkamp, M.; Young, S.B. In support of open-loop supply chains: Expanding the scope of environmental sustainability in reverse supply chains. J. Clean. Prod. 2019, 214, 573-582. [CrossRef]

53. Rajendran, S.; Scelsi, L.; Hodzic, A.; Soutis, C.; Al-Maadeed, M.A. Resources, Conservation and Recycling Environmental impact assessment of composites containing recycled plastics. Resour. Conserv. Recycl. 2012, 60, 131-139. [CrossRef]

54. Krivtsov, V.; Wäger, P.A.; Dacombe, P.; Gilgen, P.W.; Heaven, S.; Hilty, L.M.; Banks, C.J. Analysis of energy footprints associated with recycling of glass and plastic-Case studies for industrial ecology. Ecol. Model. 2004, 174, 175-189. [CrossRef]

55. Zorpas, A.A. Strategy development in the framework of waste management. Sci. Total Environ. 2020, 716, 137088. [CrossRef]

56. De Oliveira, C.T.; Mônica, M.M.M.; Campos, L.M.S. Understanding the Brazilian expanded polystyrene supply chain and its reverse logistics towards circular economy. J. Clean. Prod. 2019, 235, 562-573. [CrossRef]

57. Mazzocchi, G.; Marino, D. Rome, a Policy without Politics: The Participatory Process for a Metropolitan Scale Food Policy. Environ. Res. Public Health 2020, 17, 479. [CrossRef] [PubMed]

58. Cuomo, F.; Lambiase, N.; Castagna, A. Living lab on sharing and circular economy: The case of Turin. Health Inform. J. 2021, 27, 1-12. [CrossRef] [PubMed]

59. Nelson, E. How Interface Innovates with Suppliers to Create Sustainability Solutions. Glob. Bus. Organ. Excell. 2009, 28, 22-30. [CrossRef]

60. Rajala, R.; Westerlund, M.; Lampikoski, T. Environmental sustainability in industrial manufacturing: Re-examining the greening of Interface's business model. J. Clean. Prod. 2016, 115, 52-61. [CrossRef]

61. Diener, D.L.; Tillman, A.M. Component end-of-life management: Exploring opportunities and related benefits of remanufacturing and functional recycling. Resour. Conserv. Recycl. 2015, 102, 80-93. [CrossRef]

62. Zhou, G.; Gu, Y.; Wu, Y.; Gong, Y.; Mu, X.; Han, H.; Chang, T. A systematic review of the deposit-refund system for beverage packaging: Operating mode, key parameter and development trend. J. Clean. Prod. 2020, 251, 119660. [CrossRef]

63. Vanegas, P.; Peeters, J.R.; Cattrysse, D.; Tecchio, P.; Ardente, F. Ease of disassembly of products to support circular economy strategies. Resour. Conserv. Recycl. 2018, 135, 323-334. [CrossRef]

64. Pike, K.R.; Desroches, C.T. Virtual Consumption, Sustainability and Human Well-Being. Environ. Values 2019, 29, 361-378. [CrossRef]

65. Vendrell-Herrero, F.; Bustinza, O.F.; Parry, G.; Georgantzis, N. Servitization, digitization and supply chain interdependency. Ind. Mark. Manag. 2017, 60, 69-81. [CrossRef]

66. Kasulaitis, B.V.; Babbit, C.W.; Krock, A.K. Dematerialization and the Circular Economy Consumer Electronic Product Ecosystem. J. Ind. Ecol. 2018, 23, 119-132. [CrossRef]

67. Fauré, E.; Finnveden, G.; Gunnarsson-Östling, U. Four low-carbon futures for a Swedish society beyond GDP growth. J. Clean. Prod. 2019, 236, 117595. [CrossRef]

68. Barsnes, Z.I.; Diekmann, K.A.; Seidel, M.-D.L. Motivation and opportunity: The role of remote work, demographic dissimilarity, and social network centrality in impression management. Acad. Manag. J. 2005, 48, 401-419. [CrossRef]

69. Neufeld, D.J.; Fang, Y. Individual, social and situational determinants of telecommuter productivity. Inf. Manag. 2005, 42, 1037-1049. [CrossRef]

70. Bloom, N.; Liang, J.; Roberts, J.; Ying, Z.J. Does working from home work? Evidence from a chinese experiment. Q. J. Econ. 2015, 130, 165-218. [CrossRef]

71. Formanek, M.; Wenger, M.C.; Buxner, S.R.; Impey, C.D.; Sonam, T. Insights about large-scale online peer assessment from an analysis of an astronomy MOOC. Comput. Educ. 2017, 113, 243-262. [CrossRef]

72. Baggaley, J. MOOC rampant. Distance Educ. 2013, 7919, 368-378. [CrossRef] 
73. Magnier, L.; Mugge, R.; Schoormans, J. Turning ocean garbage into products-Consumers' evaluations of products made of recycled ocean plastic. J. Clean. Prod. 2019, 215, 84-98. [CrossRef]

74. Rammou, E.; Mitani, A.; Ntalos, G.; Koutsianitis, D.; Taghiyari, H.R.; Papadopoulos, A.N. The potential use of seaweed (Posidonia oceanica) as an alternative lignocellulosic raw material for wood composites manufacture. Coatings 2021, 11, 69. [CrossRef]

75. Moya-Clemente, I.; Ribes-Giner, G.; Chaves-Vargas, J.C. Sustainable entrepreneurship: An approach from bibliometric analysis. J. Bus. Econ. Manag. 2021, 22, 297-319. [CrossRef]

76. Schaltegger, S.; Wagner, M. Sustainable entrepreneurship and sustainability innovation: Categories and interactions. Bus. Strateg. Environ. 2011, 20, 222-237. [CrossRef] 